\title{
A review of Lassa fever cases in Nigeria for the year 2020
}

\section{Iveren Winifred Nyinoh ${ }^{1 *}$, Laura Nguoron Utume ${ }^{1}$, Ooja Bob-Echikwonye ${ }^{2}$}

\author{
${ }^{1}$ Department of Biological Sciences, Benue State University, Makurdi, Benue State, Nigeria \\ ${ }^{2}$ Department of Community Health, Benue State University Teaching Hospital, Makurdi, Benue State, Nigeria
}

Received: 18 February 2021

Revised: 18 March 2021

Accepted: 23 March 2021

\section{*Correspondence: \\ Dr. Iveren Winifred Nyinoh, E-mail: inyinoh@bsum.edu.ng}

Copyright: ( ) the author(s), publisher and licensee Medip Academy. This is an open-access article distributed under the terms of the Creative Commons Attribution Non-Commercial License, which permits unrestricted non-commercial use, distribution, and reproduction in any medium, provided the original work is properly cited.

\begin{abstract}
Lassa fever (LF) is a zoonotic disease endemic in west Africa and the knowledge of its epidemiology is important in the prevention of infection. In Nigeria, LF occurs majorly in the dry months and individuals in rural communities are mostly infected, however, there have been reports of a shift to urban households. Clinical symptoms vary and may be non-specific thus making diagnosis challenging. In this paper, we reported data routinely collected in 2020 from all individuals diagnosed with LF in Nigeria. Data were obtained from the Nigerian centre for disease control (NCDC) website online. Out of 6791 suspected cases from 30 December 2019 to 3 January 2020 there were 1189 laboratoryconfirmed cases and 244 deaths. By comparison to the same period in 2019 where there were 833 cases and 74 deaths, this represents an increase of $42.74 \%$ confirmed cases from 2019. Data indicates that there was a minimum of 1 confirmed case of LF in 131 local government areas across 27 of the 36 states. Ondo state Nigeria had the highest number of confirmed cases with 75\%, which was followed by Edo (32\%) and Ebonyi (7\%). By age, the 21-30 year old were mostly affected. Collated data showed the numbers of LF cases are significantly increasing yearly. The results obtained will assist the government in mapping the disease and taking precautionary measures to prevent the spread of LF amongst individuals in Nigeria.
\end{abstract}

Keywords: Lassa virus, LF, Epidemiology, Clinical pathology, Prevention, Nigeria

\section{INTRODUCTION}

\section{Epidemiology of LF}

LF disease was named after Lassa, the town in Borno state, Nigeria where it was first discovered in 1969 resulting in the death of the first cases of two missionary nurses who died from a febrile ailment. ${ }^{1}$ In west Africa, the case-fatality rate of LF is $1 \%$. Though estimates for LF are basic and not standardized, approximately $100,000-300,000$ infections occur in west Africa yearly with nearly 5,000 mortalities. ${ }^{2} \mathrm{LF}$ is a viral hemorrhagic fever caused by the pathogenic agent Lassa virus (LASV), a single-stranded RNA virus of the genus Mammarenavirus and Arenaviruse family. ${ }^{3-5}$ The disease is predominantly endemic to select sub-Saharan African countries predominantly in Nigeria, Guinea, Sierra Leone. ${ }^{6-8}$ Sogoba and colleagues purport to indications of a spread in the LASV-endemic regions. ${ }^{9}$ Similarly, there have been indications of the LASV being endemic in the central African Republic, Senegal, Ghana, Burkina Faso, and Cameroon. ${ }^{10-12}$ However, data obtained resulted from the investigation of the serological prevalence of rodents. Thus, seropositivity could have been from infection with LASV or infection resulting from similar arenaviruses.

\section{Transmission of $\mathrm{LF}$}

LF can affect individuals of all ages and all sexes. ${ }^{6}$ The incubation period of the LASV is reported to be 6-21 days. From infection, excretion of the virus in the urine occurs three to nine weeks, while it is three months in 
semen. ${ }^{13}$ The outbreak of LF is seasonal. In Nigeria, peak cases of LF outbreak are highest during the dry season months of December-April. The mastromy rats are responsible for transmitting the disease and reproduce in the rainy season months of May-June. Following the reproduction cycle, peak cases are usually observed in Nigeria in December-April. ${ }^{14}$ As a rodent-borne zoonotic disease, humans become infected with LASV by consuming food contaminated with urine and faeces from infected Mastomy's natalensis, a multi-mammate rat. ${ }^{15}$ Besides human to human transmission can also occur through the body fluids of infected persons. ${ }^{16}$

\section{Clinical manifestations}

The natural reservoir though infected with the virus does not show any signs of illness yet sheds viruses in the waste matter (urine or faeces). Clinically approximately 80 percent of individuals infected with LF are asymptomatic. ${ }^{17,18}$ However in individuals that come down with the disease, clinical symptoms vary and range from acute and potentially fatal hemorrhagic fever, a disorder denoted as LF, characterized by failure of multiple organs namely liver, spleen, and kidney. ${ }^{6,19}$ Symptoms can be confused with regular diseases such as malaria and typhoid that are prevalent in the region. This ambiguity poses a problem for the detection of infected patients. $^{20,21}$

\section{Lassa fever therapy}

At present, there is no approved prophylaxis or therapy for Lassa fever, and limited treatment for instance ribavirin exists for the management of the disease with various levels of clinical efficacy. ${ }^{7,17}$ However, four LF virus lineages (I, II, III, IV) have been identified, with lineages I-III common in Nigeria and lineage IV unique to Sierra Leone. ${ }^{8}$ This diversity in genetic variation is thought to be a major challenge confronting vaccine development, whilst also contributing to underemphasizing its occurrence., $3,22,23$ The ML29 candidate vaccine presently under development has been evaluated in nonclinical studies using mice models for the likelihood of offering protection against the virus. This study was undertaken using a LF virus strain from clade II, that resulted in the worst documented outbreak in Nigeria to date. ${ }^{24}$ The results were encouraging, revealing positive results with effective protection. ${ }^{17}$

\section{Description of the study country}

Nigeria is a country of approximately 200 million people and has 774 local governments across the 36 states including the federal capital territory (FCT). Nigeria is also sometimes characterized by geopolitical regions namely north-central, north-east, north-west, south-west, south-east and south-south. The majority of the country enjoys a tropical climate; however, the far northern countries have a semi-arid climate. Nigeria has variable seasons; the dry season is characterized by low night temperatures and winds from the Sahara desert and typically runs from November to early March. The length of the rainy season differs from north to south. In the northern part of Nigeria, the rains can begin as late as June/July and end in September while in southern Nigeria, the rains begin in April, peaks in June, and ends in July. There are currently five laboratories Di national reference laboratory, Gaduwa, FCT, Irrua specialist teaching hospital, Edo state, Lagos university teaching hospital (LUTH), federal teaching hospital, Abakaliki, Ebonyi state and federal medical centre Owo, Ondo state, that can test for LF infection from serum, while the NCDC collects surveillance data for the whole country from data collated from all LGAs and states via the integrated disease surveillance and response (IDSR) platform and provides the weekly epidemiological reports that were utilized in this study.

\section{Investigation of the 2020 LF cases in Nigeria}

Data of the diagnosed LF population in Nigeria was obtained from the NCDC website. This data is expected to be representative of the Nigerian population because the data collected was from all the geopolitical zones. Using the figures (available from the NCDC) from 30 December 2019 through to 3 January 2021, 6791 cases of LF were suspected, of which, 1189 were confirmed laboratory cases and 244 deaths in Nigeria, representing a $42.74 \%$ increase from 2019. Out of the 36 Nigerian states, 27 states, across 131 local government areas documented a minimum of 1 confirmed case. At $75 \%$, Ondo state had the highest percentage of confirmed cases, followed by Edo State (32\%) and Ebonyi (7\%) states respectively. There were several limitations. Firstly, we utilized secondary data already collected and obtained from the NCDC website online. Also, we only collected data on the numbers of laboratory-confirmed LF patients and the average age of the infected patients.

\section{DISCUSSION}

In this report, the number of laboratory-confirmed LF cases in Nigeria for the year 2020 and the most affected age group is reported. There were a suspected 6791 LF cases from 30 December 2019 to 3 January 2021. The high numbers of suspected cases are supported to some extent by the fact that LF diagnosis is non-specific, as LF clinical manifestations cut across some of the commonly available ailments in the region (malaria, typhoid) making diagnosis challenging. ${ }^{20,21}$

The numbers of laboratory-diagnosed patients were 1189 and 244 people died from the infection in 2020. By comparison to the figures obtained during the same period in 2019, 833 LF cases were confirmed in the laboratory indicating a substantial increase of $42.74 \%$; 174 mortalities were recorded. Thus, this has implications for the proper diagnosis and management of LF. 
The distribution of LF is unequal within Nigeria. The percentage of laboratory-confirmed LF cases in the southern-western state of Ondo $(75 \%)$ is over twice as much as that for Edo state $(32 \%)$ with Ebonyi showing the least $(7 \%)$. Keita et al reports that LF can traverse land boundaries quickly. ${ }^{25}$ Thus, the high percentage of LF in these two states is not surprising as Ondo shares a land border with Edo state, Nigeria. Similarly, according to Hallam et al areas with large forest portions are expected to have huge reservoirs of Mastromy rats that are responsible for transmitting the LASV to humans. ${ }^{26}$ This may be the reason for the high percentages of LF confirmed cases in the affected states as these states have several forests that may serve as reservoirs for $\mathrm{LF}$ vectors.

From the data obtained from the NCDC website, the distribution of LF varies with individuals age in the Nigerian population and was predominant in young people $<30$. This is similar to what is obtained in other west-African countries. For instance in studies conducted in Liberia between 2008-2012, many young adults were infected with LF. Their average ages of LF infected patients was $28 .{ }^{27}$

\section{CONCLUSION}

The number of laboratory-confirmed cases of LF from 2019, which was 833 and 174 deaths, shows an increase in the number of LF cases in Nigeria. Furthermore, the results indicate that southern Nigerian states had more cases as indicated by Ondo, Edo and Ebonyi. There is therefore an urgent need for community education on hygiene, for instance on poor sanitation, crowded living that could increase the chances of individuals coming in contact with infected rodents in residential homes. Similarly, enlightenment on the most appropriate means of handling food e.g. sun-drying foods by the roadside should be stopped and also in the Nigerian tribes that still eat rats, massive enlightenment should be carried out in those communities. Furthermore, there is a need for additional laboratories and treatment centres in Nigeria to decrease the numbers of LF.

\section{ACKNOWLEDGEMENTS}

We would like to thank NCDC for the surveillance data.

Funding: No funding sources

Conflict of interest: None declared

Ethical approval: Not required

\section{REFERENCES}

1. Frame JD, Baldwin JMJ, Gocke DJ, Troup JM. Lassa fever, a new virus disease of man from west Africa. Am J Trop Med Hyg. 1970;19(4):670-6.

2. CDC. Lassa fever, 2019. Available at: https://www.cdc.gov/vhf/lassa/index.html. Accessed on 11 February 2021.
3. Andersen KG, Shapiro BJ, Matranga CB, Sealfon R, Lin AE, Moses LM et al. Clinical sequencing uncovers origins and evolution of Lassa virus. Cell. 2015;162(4):738-50.

4. Radoshitzky SR, Bao Y, Buchmeier MJ, Charell RN, Clawson AN, Clegg CS et al. Past, Present, and future of arenavirus taxonomy. Arch Virol. 2015;160(7):1851-74.

5. Yun NE, Walker DH. Pathogenesis of Lassa fever. Viruses. 2012;4(10):2031-48.

6. World Health Organization. Lassa Fever, 2017 Available at: https://www.who.int/en/newsroom/fact-sheets/detail/lassa-fever. Accessed on 5 February 2021.

7. Mire CE, Cross RW, Geisbert JB, Borisevich V, Agans KN, Deer DJ et al. Human-monoclonalantibody therapy protects nonhuman primates against advanced Lassa fever. Nat Med. 2017;23(10):1146-9.

8. Shaffer JG, Schieffelin JS, Grant DS, Goba A, Momoh M, Kanneh L, et al. Data set on Lassa fever in post-conflict Sierra Leone. Data Brief. 2019;16:23:103673.

9. Sogoba N, Feldmann H, Safronetz D. Lassa fever in west Africa: evidence for an expanded region of S-

10. Fichet-Calvet E, Rogers DJ. Risk maps of Lassa fever in west Africa. PLoS. Negl. Trop. Dis. 2009;3:e388.

11. Kouadio L, Nowak K, Akoua-Koffi C, Weiss S, Allali BK, Witkowski PT et al. Lassa virus in multimammate rats, Côte d'Ivoire, 2013. Emerg Infect Dis. 2015;21(8):1481-3.

12. Mylne QNA, Pigott DM, Longbottom J, Shearer F, Duda KA, Messina JP et al. Mapping the zoonotic niche of Lassa fever in Africa. Trans R Soc Trop Med Hyg. 2015;109(8):483-92.

13. World Health Organization. WHO Lassa fever fact sheet No 179. Geneva:WHO, 2000.

14. World Health Organization. Fact sheet: Lassa fever, 2020. Available at: https://www.who.int/healthtopics/lassa-fever. Accessed 11 February 2021.

15. Monath TP, Newhouse VF, Kemp GE, Setzer HW, Cacciapuoti A. Lassa virus isolation from mastomys natalensis rodents during an epidemic in Sierra Leone. Science. 1974;185(4147):263-5.

16. Akhmetzhanov AR, Asai $Y$, Nishiura $H$. Quantifying the seasonal drivers of transmission for Lassa fever in Nigeria. Philos Trans R Soc Lond B Biol Sci. 2019;374(1775):20180268.

17. Johnson DM, Jokinen JD, Lukashevich IS. Attenuated replication of Lassa virus vaccine candidate $\mathrm{ml} 29$ in stat-1(-/-) mice. Pathogens. 2019;8(1):9.

18. Richmond JK, Baglole DJ. Lassa fever: epidemiology, clinical features, and social consequences. BMJ. 2003; 327(7426):1271-5.

19. McCormick JB, King IJ, Webb PA, Johnson KM, O'Sullivan RO, Smith ES et al. A case-control 
study of the clinical diagnosis and course of lassa fever. J Infect Dis. 1987;155(3):445-5.

20. Akhuemokhan OC, Ewah-Odiase RO, Akpede N, Ehimuan J, Adomeh DI, Odia I et al. Prevalence of Lassa virus disease (LVD) in Nigerian children with fever or fever and convulsions in an endemic area. PLoS Negl Trop Dis. 2017;11(2):e0005711.

21. Okokhere P, Colubri A, Azubike C, Iruolagbe C, Osazuwa O, Tabrizi S et al. Clinical and laboratory predictors of Lassa fever outcome in a dedicated treatment facility in Nigeria: a retrospective, observational cohort study. Lancet Infect Dis. 2018;18(6):684-95.

22. Bowen M, Rollin PE, Ksiazek TG, Hustad HL, Buasch DG, Demby AH et al. Genetic diversity among Lassa virus strains. J Virol. 2000;74(15):6992-7004.

23. Emmerich P, Gunter S, Schmitz H. Strain-specific antibody response to Lassa virus in the local population serpof West AFrica. J Clin Virol. 2008;42(1):40-4.
24. Roberts L. Nigeria hit by unprecedented Lassa fever outbreak. Science. 2018;359(6381):1201-2.

25. Keïta M, Kizerbo GA, Subissi L, Traoré FA, Doré A, Camara MF et al. Investigation of a cross-border case of Lassa fever in West Africa. BMC Infect Dis. 2019;19:606.

26. Hallam HJ, Hallam S, Rodriguez SE, Barrett ADT, Beasley DWC, Chua A et al. Baseline mapping of Lassa fever virology, epidemiology and vaccine research and development. NPJ Vacc. 2018;3:11. Olugasa BO, Dogba JB. Mapping of Lassa fever cases in post-conflict Liberia, 2008-2012: a descriptive and categorical analysis of age, gender and seasonal pattern. Ann Afr Med. 2015;14(2):1202.

Cite this article as: Nyinoh IW, Utume LN, BobEchikwonye O. A review of Lassa fever cases in Nigeria for the year 2020. Int J Community Med Public Health 2021;8:2572-5. 